\title{
クレームを通してみた米国(カリフォルニア州)の 契約マネジメント
}
（株）アイ・エス・エス
中村 裕司*1
石川島播磨重工業（株）
石川島播磨重工業（株）
○柳原 正浩*2
小濱 吉記*3

By Yuji NAKAMUA, Masahiro YANAGIHARA, Yoshiki KOHAMA

欧米流の建設マネジメント手法の研究が日本でも積極的に行われている．また，一部を 日本型に改良した手法を導入しつつもある。一方，米国社会をクレーム社会，契約社会と 認識しながらもその実像を体験的に理解している日本人は多くない．本稿は，グローバル 化を目指す日本の建設業，あるいは日本における今後の建設契約の進展に供するため，筆 者らが直面した橋梁建設工事におけるクレームの提起と解決を通し，米国の契約マネジメ ントについて解説し考察する.

本稿では，米国カリフォルニア州において実施した建設契約をもとに，

（1）契約並びに工事に関わる紛争解決手順とそのメリット，デメリット

（2）工期延長や設計変更並びに請負範囲変更に関する係争事例とクレーム提起及び係争 解決の要点

について事例を交えながら一般論としての筆者らの考えを述べる.

また，米国のようなクレーム・契約社会で，外国企業という立場から対等に交涉を進め ることが出来る契約マネジメントのあり方について提言する.

【キーワード】米国, 契約, 紛争解決, 補償

\section{1.はじめに}

米国は，契約社会あるいはクレーム社会と言われて いる. Longman 辞書によると，クレーム（Claim）とは "to state that something is true, even though it has not been proved"

または,

"to state that you have a right to something or take something belong to you"

とある。

すなわち，クレームとは正当な権利の主張であり， 日本でいう苦情（complaint）とは根本的に異なる.

クレームを提起する際, 正当な権利の根拠となるの が契約書である。これを米国人、け “Per Spec（契約書
通り）”と表現する.

このように契約社会・クレーム社会とは，正当な根 拠に則った権利をはっきりと主張し，定められた規準 に沿って解決を行う社会である。したがって，米国の 契約制度やクレーム手続きから日本が研究すべき建 設マネジメント上のテーマは多い.

特に近年，納税者に対する説明責任の向上が問われ ている日本において，発注プロセスの透明性，請負者 の履行責任，あるいは第三者機関による発注者や請負 者の行為に対するモニタリングという観点から，米国 の建設マネジメントシステムが日本の建設マネジメ ントシステムを改善する上で寄与する部分は少なく ない.

ただ，新システムを導入しようとする場合には，そ

* 1 代表取締役社長 $03-5768-0435$ 
れを受け入れるだけの精神的改革が基盤になる. 日本 のように, 発注者権限が大きい社会では, まず発注者 側から「変化を受容する」態度を持つことが肝要では ないか.

本稿は，米国カリフォルニア州交通局が発注する橋 梁建設工事の経験をもとに，原初契約からの変更に伴 って生じるクレームの提起と解決を中心に，米国にお ける契約マネジメントシステムの手続きの透明性に ついて解説し，その長短を考察する.
2.では建設契約における紛争解決の諸手法につい て述べる．３．では工期延長に関連する紛争の解決, 4.では契約範囲変更に関わる紛争の解決について, それぞれ議論する．5．で契約マネジメントのあり方 について，クレーム事例を用いながら一般論としての 筆者らの考えを述べる.

\section{2. 紛争解決の諸手法}

カリフォルニア州の橋梁工事の場合, 契約から完工 まで主要な進渉過程ごとに, 紛争解決の手法が契約の

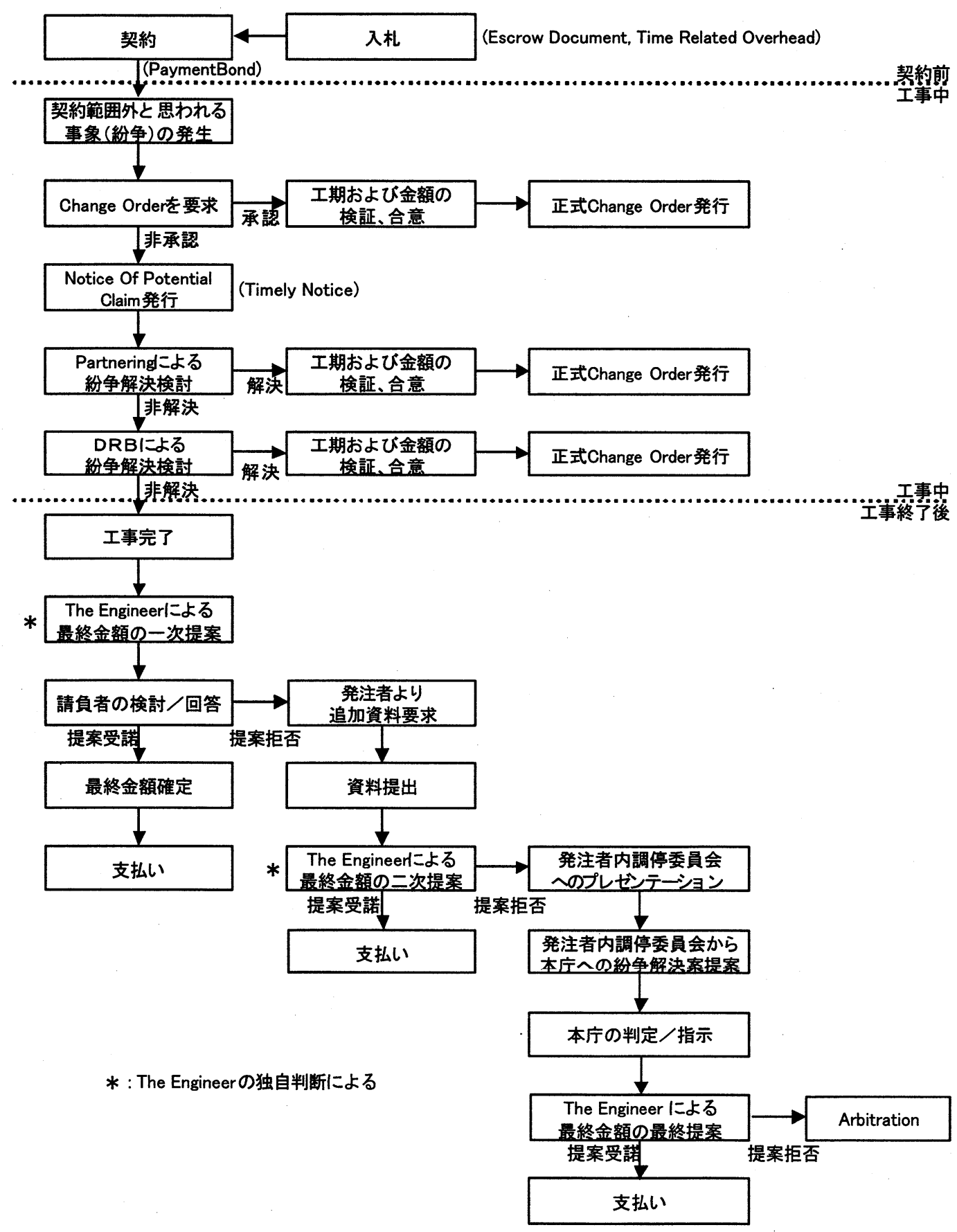

図ー1 紛争解決の視点から見たエ事フロー 
中に組み込まれていた ${ }^{1)}$ (図一1参照）。

これは，米国の建設マネジメントが『経過を見せる マネジメント手法』として成熟しつつある証左の一つ である。

他方，日本においては，発注者と受注者の双方が作 業経過にできるだけ口をはさまず，相互信頼を通じて 円滑に遂行しようとする『信義則』が基盤である ${ }^{2)}$. とは言え、日本の発注の場合、入札図書と異なる解釈 を決定する時は、打合覚等により発注者の了解を得て いる習慣が定着しており一概には断定できないが、相 互不可侵の領域が拡大すれば，外部に対する透明性は 低下する，透明性の向上という点で，米国の先進性を 認めることができる.

以下にカリフォルニア州交通局の施工契約を例に, 主要な紛争解決手法について以下に説明する.

\section{（1）入札・契約時の紛争解決条項 ${ }^{3) ~ 6) ~}$}

日本では, 契約の締結にあたり紛争を想定し, 紛争 解決手法を具体的に規定する事例は少ない，一つは発 注者の権限が大きいためであり，他の一つは日本の建 設契約は『信義則』を背景にしているためである.

反面米国では，契約にいたる過程で工事途中の紛争 発生を想定し, 速やかな解決を助長する条項をあらか じめ定めておく，発注者と受注者の対等性が，契約の 具体的条項にしたがって明確にされている. 代表的な 条項を以下に解説する.

(1) Escrow Document (捺印証書)

Escrow Document とは，入札者が入札金額を策定す るに到った裏づけ資料（工事金額見積根拠，工期試算 根拠など）を保管するものである. 将来紛争が発生し た場合，契約に到った金額的根拠や工期的根拠まで遡 及する必要が生じた時に活用する.

入札者（時には，下請も含む）は裏づけ資料を発注 者の立会いのもと第三者機関へ預ける. 預託後はこの 書類は封印され, 発注者と受注者の両者の合意がない 限り引き出すことは出来ない.

(2) Time Related Overhead (工期関連の間接費) ${ }^{3) \sim 6)}$

建設契約において多発する紛争のひとつに工期変 更がある. Time Related Overhead とは，工期変更が 生じた場合に, 変更期間に相当する間接費を入札者が 入札時に設定しておくものである.

ただし，入札者はこの間接費を，入札金額の構成要 素として組み込まなければならないため，染意的に割
り増すことは入札者にとって不利である。

紛争が生じた場合，直接工事費に比べ間接費の査定 は困難であったが，この手法が導入されたことにより 工期変更に伴う間接費が明確化される.

日本の建設契約においても導入を考慮してよい公 正な規定である.

(3) Payment Bond（支払い保証）

発注者は元請に対し，下請保護の一環として支払保 証を要請する. これを Payment Bond という. 日本で も最近『ボンド制の導入』に係わる議論が活発である が, その対象は元請の履行責任の保証 (Performance Bond）が中心であり，下請への支払保証については議 論が未成熟である. 従来、元請けは「支払い」という 行為を武器に、下請けに対し優位な立場にあった。 Payment Bond 制度を導入することにより、支払い行為 は武器にならず、紛争の際、両者は同じ土俵に上がる ことになる.ここにも, 米国での発注者一元請一下請 相互の契約上の対等性が窥える，日本でもさらに活発 な議論が必要と考える.

カリフォルニア州では, 元請契約金額の $100 \%$ を保証 させるのが標準 3)であるが，大規模工事の場合低減さ れる場合もある。この手法は，発注者が元請・下請の 支払いに伴う紛争に介入しないと同時に，下請への支 払を第三者が保証する点が特徴である. 元請による支 払が停滞した場合，下請は第三者へ支払いを求めるこ とができる.

\section{（2）施工途中の紛争解決手法}

発注者が絶大な権限をもつ日本では，請負者が発注 者を相手取って紛争を起こす事例は稀有である. 一方, 発注者と請負者は果たすべき機能が異なるだけであ って立場は対等とする米国では，原初契約に則った義 務の履行あるいは権利の要求に係わる紛争は日常的 である. したがって，施工途中に生じる紛争に関して も，周到に紛争解決手法が規定されている.

表一 1 は，発注者と請負者の間の紛争解決手法とそ

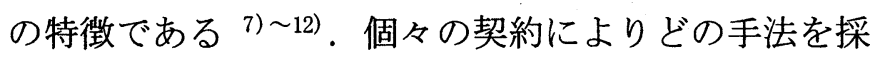
択するかは, 双方が戦略的に策定する. 以下, 日本で は導入されていないパートナリング (Partnering) と DRBについて解説する.

(1) パートナリング (協働) 7)

パートナリングは, 発注者と請負者で構成し、紛争 解決のためのひとつの手法である. 課題に応じて, 主 
表-1 紛争解決手法

\begin{tabular}{|c|c|c|c|c|c|}
\hline 紛争解決手法 & Partnering & DRB & Mediation & Arbitration & Litigation \\
\hline 開催時期 & $\begin{array}{l}\text { 工事期間中 } \\
\text { (定期的) }\end{array}$ & $\begin{array}{c}\text { 工事期間中 } \\
\text { (必要に応じて) }\end{array}$ & $\begin{array}{c}\text { 原則, 工事中 } \\
\text { または工事終了後 }\end{array}$ & 原則, 工事終了後 & 原則, 工事終了後 \\
\hline $\begin{array}{c}\text { 発注者, 請負者 } \\
\text { 以外の参加 }\end{array}$ & Facilitator & $\begin{array}{c}\text { Dispute Review } \\
\text { Board Member }\end{array}$ & Mediator & Arbitrator & $\begin{array}{c}\text { Judge Attorney } \\
\text { Jury }\end{array}$ \\
\hline 解決の手法 & $\begin{aligned} & \text { 話し合い } \\
& \rightarrow \text { 両者の合意 }\end{aligned}$ & $\begin{array}{l}\text { プレゼンテーション } \\
\rightarrow \text { Board 提案 }\end{array}$ & $\begin{array}{c}\text { Mediator を介して } \\
\text { の両者合意 }\end{array}$ & $\begin{array}{l}\text { 資料提出, 公聴 } \\
\rightarrow \text { Arbitrator 裁定 }\end{array}$ & 判決 \\
\hline 提案の拘束力 & なし & なし & なし & $\begin{array}{l}\text { 基本的に“あり” } \\
\text { (“なし”もある) }\end{array}$ & あり \\
\hline 費用 & 小 & 小 & 中 & 大 & 大 \\
\hline 解決までの期間 & 即時 & 1〜 3 ケ月程度 & 1〜 6 ケ月経度 & 6 力月～2 年 & 1 年超 \\
\hline
\end{tabular}

要な下請も参加する.

パートナリング会議では, ファシリテーターが進行 を努める．発注者と受注者が契約の円滑な遂行を目指 し，そのために必要な策定事項と課題を明確にした上 で，双方が協力または譲歩しうる解決策を助長するこ とが，パートナリングの目的である.

定期的に開催され，紛争に到る以前に解決を試みる 手法として有効である. 細かい紛争のタネの多くはこ の手法で解決される.

(2) Dispute Review Board (紛争解決委員会) 7) 8)

時には、パートナリングが十分に機能しない場合が ある、例えば、契約書の表現が十分明膫と言えず、契 約書の解釈に、両者間で根本的な違いがあるような場 合である。このような時, 発注者と請負者は当該専門 分野の有識者による解決を要請する. それを D R B と いう.

D R B は, 経験・専門知識を有する第三者の中から， 発注者が推薦する者, 請負者が推薦する者, その両者 が推薦する者, 各 1 名によって構成する. 両者推薦の 1名は, 大学教授あるいは当該領域の有識者が任命さ れ，委員会の代表となる.

D R B では発注者，請負者がそれぞれの主張をプレ ゼンテーションする. 双方の主張をヒアリングした後, D R B は紛争解決のための意見書を推奨する. D R B の意見書には拘束力はなく, 不服の場合には，工事終 了後に用意されている紛争解決手法の中から『調停』 や『仲裁』を選択する.
パートナリングやD R B は，工事が進渉する過程に おいて発生する紛争を、それぞれの段階で解決してい くための独立した周到な手段である. 完成期日の延期 に対する影響を最小限にとどめる手法として有効と いえる.

\section{（3）工事終了時における紛争解決システム}

既存橋梁の修繥や更新が中心を占めている米国の 橋梁建設契約では，供用中の交通を遮断しながら工事 を実施せざるを得ず，工期の延伸は最も避けるべき事 態である。

このため工事進渉途中に，むやみに訴訟や調停が生 じることは好ましくない，なぜなら，中断による不必 要な工事遅延を生じるからである.

このような事態を避けるため, 契約書には一次提案, 二次提案, 最終提案という発注者からの提案段階を設 けており, 紛争が当事者間で解決される機会を増やす と共に，双方が納得した上で調停へ進むよう，枠組み している3) 9).

なお，上記枠組みは発注者が提案するものであり， 請負者はその提案を承諾するか否かを判断する. 第三 者が加わることはない.

\section{（4）米国紛争解決手法に関する考察}

以上のように，米国には日本にはない紛争解決手法 がいくつかある．したがって，米国や類似契約概念を 採用する国において建設契約を締結する場合，この手 法に関するメリット，デメリットを理解しておくこと 
は重要である。

(1)メリット

- 紛争解決手順が契約書に明記されており, 請負者 の当然の権利として位置付けされているため，発 注者，請負者が対等に話し合える.

- 契約書は, 紛争発生を前提として構築されている ため，紛争の解決を助長することができる.

・第三者が関わることにより客観的判断が行われる ため, 紛争結果に対し当事者に不信感が残りにく い.

・解決にあたり，責任の所在，紛争の原因，紛争の 処置が明確であるため, 納税者に対する説明責任 が容易である。

・ 紛争解決の機会が多い.

(2) デメリット

- クレームの証拠資料としては、口頭通信はほぼ無 効であり，いきおい文書主義になり多量の書類を 準備する必要がある.

- 第三者裁定を依頼する場合があるため, 紛争解決 に際し，双方に予定外の経費が発生する。

・契約条項に精通していない場合，権利を運用でき なかったり, 義務履行を意ったりする可能性が高 く, このような場合紛争解決において著しく不利 となる。（例えば, 図一1の “Notice Of Potential Claim; クレームの通知” は事象発生後, 15 日以内 と決められており，この通知を吝るとクレームす る権利すら失う。）

\section{3. 工期延長に関するクレーム}

公共工事標準請負契約約款第三条（a ）によれば、 「請負者は発注者に代金内訳書と工程表を提出し承 諾を得る。だが、これらは発注者と請負者を束縛しな い。」となってる。高知工科大 草柳教授によれば、 そのために日本では経過を見せる必然性が希薄にな っているという13).

他方米国では，契約時の完成期日は契約の前提とし た合意事項に裏打ちされた期日であるため，途中で前 提事項が覆れば，契約総額も完成期日も変更すること が当然となっている.もちろん、日本でも契約図書に よれば前提条件が覆れば完成期日、契約金額を変更す る規定になっている、だが、米国ほど頻繁かつ多様な 請負者による要請が生じる事例は寡聞である.
つまり，米国の建設契約は経過を見せる必然性を伴 っている. この点, 日本の建設契約が米国から学ぶ手 法は多い.

ここでは，工期延長に関するクレームについて考察 する.

\section{（1）工期延長クレームの必要条件}

一般に，以下の条件を満足しかつそれを証拠立てる 書類が整えば工期は延長できる。

(1) 原因：工期を延長する理由が, 原初契約の範囲外 であり，かつ，その発生原因が請負者の責任では ないこと.

(2) 全体工期への影響 : 全体工期に影響すること.ク リティカルパスに影響する作業に遅れが発生して いること.

(3) 代替案 : 工期を延長せず，人員や資機材を追加投 入する等の回復措置にくらべ，工期を延長する費 用の方が少ないと試算されること.

(4) 通知: 工期延長理由が発生した日から数えて, 規 定内の適切な時期に工期延長要求を提出している こと.

例えば，契約外工事の追加発注，異常気象，ストラ イキ，第三者による工事妨害など請負者が管理できな い出来事の発生, 関連・隣接工区の遅れ, 地盤条件の 変更, 過剩品質要求, 承認図書等に対する回答遅れ等, 工期延長の理由は広範である.

\section{（2）工期延長の処理}

前項のような理由が証明された場合，延長日数が確 定する. 請負者の責任によらない遅れと, 請負者の責 任による遅れが複合した理由になっている場合（これ を “Concurrent Delay”という）には，完成期日の延 長のみ変更される場合がある，請負者の責任によらな い理由のみで遅れた場合には，完成期日の変更と同時 に契約金額も変更する.

遅れに伴う請負者の追加費用は，以下により算定す る.

a ) 直接費

機材のレンタル期間の延長，作業員の契約期間の延 長, 資材の有効期限切れに伴う再調達費用といった直 接費用は，支払証明書により増額分を認められる.

b ）間接費

(1) 間接費比率の固定 元請から下請への発注費は直 接費であり，そこには元請の間接費用が入ってい 
ない.これを救済するため, カリフォルニア州で は間接費を契約時から固定している．例えば，材 料発注については発注額の $15 \%$ ，下請発注に対し ては $5 \%$ ，追加労務者に対しては $33 \%$ を元請間接 費として規定している。この料率でも吸収できな いような間接費が発生し，それをクレームとして 要求する場合には, CPA Audit Report（公認会計 士の監査証明）を沿えて請求することを義務付け ている.

(2) Time Related 0verhead（時間関連間接費）工事 量と直接関係がなく、工事期間の延長に起因する 間接費は，(1)方法でも救済されない。カリフォ ルニア州では, これらの時間関数の間接費につき, 前述のように Time Related Overhead という規定 を設け一日あたりの間接費を，入札時に確定して いる.

\section{（3）工期に関わる紛争}

\section{（事例その1：客先↔元請け下請け間の紛争）}

実際の紛争事例として，筆者らの鋼桁製作工場に常 駐した発注者の検査官が，十分な権限委譲を受けてい なかったことに起因し，工期遅れが発生した事例を挙 げる.

a ）契約上の規定

楏約書は，工場の製作期間中，楧査官が常駐するこ とを義務付けている．検查官の権限に関する契約書上 の明瞭な規定はない，一般に検査官は，検查は行なう が仕様書の解釈や工学的判断は加えない. それは, 仕 様書上 the Engineer のみが行なうとされる.

b ）遅れの発生

一般に鋼析を製作する場合，溶接による変形を補正 するため加熱によって歪取を行なうことは特例では ない.一方, AWS (アメリカ溶接基準) は「補修は, その都度エンジニアが判断する.」と記述している.

これに基づき検査官は，「歪取は補修であり，加熱 の承認はエンジニアの権限である. 検査官の権限を超 えている.」と主張した，その結果，1部材ごとに歪 形状を計測し，歪形状を報告すると共に加熱歪取りを 行なう箇所と量を提言, それを本国のエンジニアに報 告し本庁が諾否を定める, というプロセスを要請され た.

そのためにタイムリーな流れ作業が出来ず，製作を しばしば中断した。 c) 論争, Partnering

ここに内在する問題は 2 つる.すなわち(1)工場に 常駐する検査官に委譲されている権限に関する解釈, (2)歪取作業はAW S が規定する補修に該当するかに 関する解釈である.

担当者間の話し合いえでは解決できず、パートナリ ングの結果，(1)を充足するために歪取作業を承認でき る権限を本庁エンジニアから現場駐在エンジニアに 委譲させた. また, (2)については不明瞭な規定を合理 化するために, 標準変形と標準歪取要領を本国のエン ジニアに承認させ, 標準的な歪取作業は補修の対象外 とできた.

d) D R B

パートナリングによる c) の措置により, それ以降 の遅れや滞留は解消できた. だが, それ以前に, すで に一ヶ月近くの遅れが発生していたため, 請負者は当 該遅れに対する損害額を求償した.

しかし，発注者は，c）の措置は発注者の譲歩であ って請負者の権利ではないとして, 求償を承諾しなか った．両者の話し合いによる解決は暗礁に乗り上げ， 本クレームはD R Bによる解決へ移行した.

e) D R B 結果

D R B 実施後約一ヶ月して請負者のクレームを支 持する意見書が通知された。 その意見書に車者が従う ことを表明した結果，本クレームによる工期延長と， それに伴う直接費, 間接費の求償額が, 『変更命令 (Change Order)』として発行された. 筆者らのクレ 一ムが承認されたわけである.

\section{（4）工期変更クレームに関する考察}

工期に係わるクレームを提起する場合， 3 .（1） の条件を満足することをどのように証明するかが肝 要である.

通常、米国の大型工事現場では専門のスケジューラ 一を配置し，工程の進捗管理のみならず，提出書類の 日程管理, 特にクレーム等の通知日程管理を重視して いる.

工期に影響が生じる，もしくは影響が予想される場 合，スケジューラーは工程上のクリティカルパスへの 影響はもちろん，影響に伴う金額的被害を算定し，い つまでにクレーム手続きを完了すべきかを適宜把握 する. カリフォルニア州の特記仕様書のように， Primavera Project Planner というソフトの使用を勧 
奨し, 工事進渉管理システムの構築を促す場合すらあ る. 日本でも大いに活用すべき手法である.

これに反し，この種の書類作成や管理は日本人が不 得手とする領域の一つである．米国ではクレームを通 知する書類の提出を怠ったばかりに，多額のクレーム 権を消失することも皆無ではない.

工期延長に伴うクレームの提起と解決，なかんずく 間接費の処理について，米国の契約マネジメントは非 常に体系的である，一連の手間と係争する金額を比較 した場合，この体系的手法は，発注者・請負者の双方 が享受できる利点がある.

先の事例が示すように,きわめて日常的な作業が原 因であっても，契約書の解釈が多義ならば，正当な論 理の構築によって多額の請負金増加に直結する場合 もある.この事例は，発注者の検查官の権限が十分で ないために起こった遅れではあるが, 契約書の不明瞭 な条文を突き，パートナリングやD R B などの契約書 で規定されている紛争解決手法を活用し, 損害の賠償 を勝ち取った典型である。

\section{4. 契約範囲に関するクレーム}

契約の重要事項は, Price(価格)・Scope（範囲）・ Schedule（工期）に集約できる. 特に契約マネジメン トの上で重要なのが契約範囲である.

契約範囲が不明瞭であったり，契約範囲に伴う権利 と義務に対する認識が不足していると，契約の履行や 終結において係争に発展する場合がよくある.

このような背景から，契約範囲の変更や解釈の相違 は原価のみならず工程や品質の確保にも影響する.

出来るだけ簡単にして要を得た記述を用い, 発注者 と受注者が共通の理解基盤に立った契約に至ること が建設マネジメントの要諦である.

\section{(1) 契約範囲に関わる係争}

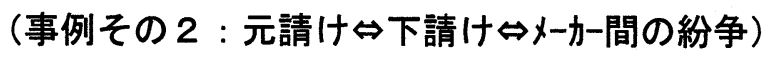

筆者らは鋼标の製作者であったが，元請からの要請 により現場継手用ボルトの供給も契約範囲とした.い わゆる調達の代行だけを範囲に含んだつもりであっ たが，契約の不備により以下のような係争に巻き込ま れた。

\section{a ) 契約関係}

日本の下請 $\mathrm{B}$ 社が米国の元請 $\mathrm{A}$ 社から鋼桁の製作 と輸送を請け負った。この契約の範囲には現場継手用

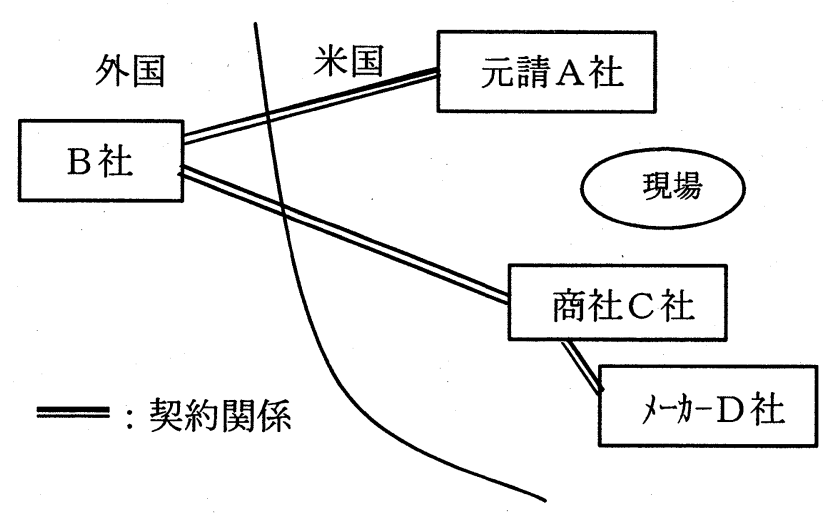

図-2 契約関係概略

ボルトの供給も含まれていた，B社はボルトの供給を 商社である C 社経由, ボルトメーカーの D社へ発注し 現場へ直送させる契約をおこなった。（図ー2）

b ）引渡し完了

B 社は契約通り，鋼桁を現場に納人し，ボルトも期 日までにD社から直接現場へ搬入し, 引渡しはいった ん完了した.

c）不具合発生

しかし，A社が，現場でボルト締めを開始し軸力を 入れた後, 緩んでいる箇所が発見された. A社は, 発 注者の検査官より製品不合格の通知を受け，早速 $\mathrm{C}$ 社 へ連絡をした. 実際のメーカーである D社は速やかに 現場へ出向き確認したが，原因を特定できなかった.

しかし発注者からの不合格通知は覆らず，D社は独 自判断で全てのボルトのリコールを決め, 新たなボル トを供給した。 $\mathrm{A}$ 社は， D 社のリコールを基に，施工 済みボルトを含め全てのボルトを取り替えた。取替え 後のボルトには問題が発生しなかった。

\section{d）損害賠償請求}

その後， A社はB $\mathrm{B}$ 社に対してボルトの取替え費用や 現場の遅れ等の費用発生を理由に後掛かり費用を請 求した， B 社はそのまま C 社へ求償したが，C社は一 切応答せず, メーカーのD社へ繋いだ.

$\mathrm{D}$ 社は「無償で新しいボルトの供給に応じたのでそ れ以上の支払いには一切応じない」と主張をした。ま た，交換についても「A社の担当から指示された期日 に交換ボルトを搬入しており，遅れ等の費用について も負担する立場にない」と主張した。

一方，A社は「契約主体であるB社は, 契約仕様書 に定められた通り発注者が拒絶した材料を無償で交 換し，交換に要した諸費用を負担する義務がある. 従 い， B 社は不合格となったボルトに起因する損害をす 
ベて賠償する責任を負っている」と主張した. その結 果， A 社はB 社に対し「B社契約額から当該損害額を 差引く」という通知を出した.

\section{e ）訴訟へ発展}

$\mathrm{B}$ 社が $\mathrm{C}$ 社へ $\mathrm{A}$ 社同様の通知を行ったところ，C社 は地方裁判所へ免責ならびに第一義責任者への求償 権を求め，契約関係にある B 社と D 社を相手に提訴し てきた. B社は契約上 $\mathrm{C}$ 社と同じ立場を取る方針を決 め, $\mathrm{A}$ 社と $\mathrm{D}$ 社間での解決を促す為, $\mathrm{A}$ 社を含めた横 断的クレーム ${ }^{12)}$ (Cross-Claim) を訴訟した. A社は, B社のボンド (Performance Bond) を発行した保険会 社も巻き込む対抗的クレーム ${ }^{12)}$ (Counter-Claim) を 申立て, 訴訟は泥沼化した。

\section{f ）調停への切替}

当事者（全て代理人弁護士）間の協議により費用及 び時間負担の少ない Mediation（調停）へ移行するこ とを合意し，裁判所へその旨を申立て裁判官より承認 が下りた。 この時点ですでにC社による提訴後 7 ヶ月 が経過していた. 裁判所の指示による調停の日程は次 の様になった。

- 裁判所の指示から約 1〜2 ヶ月で調停人の決定

・約 1 ヶ月以内：関係書類を全当事者間で交換

- 約 3 ヶ月以内：証人や有識者の候補リス卜提出

- 約 5 ヶ月以内 : 調停開催

- 約 10 ケ月以内：(調停不調和の場合)新事実を含 めた全ての証拠書類の提出.

- 約 1 年後: 裁判(第一回目公判)の日程決定

g）事実関係

調停人の選出後, 交換された関係証拠書類から以下 の事実関係が確認できた.

(1) A 社は現場継手の溶接を実施するまえにボルトを 締めていた

(2) 締めたボルトの余長分が僅かに仕様より長かった

(3) 施工要領書には仮ボルトを使用する記述がなかっ た

(4) 最初搬入されたボルトは、製作中, 多重な亜鉛入 ッキによる水素脆性の疑いがあった

(5) 全量リコールはD者の単独判断であった

（6) $\mathrm{A}$ 社はボルトの取替え作業費を $\mathrm{B} \cdot \mathrm{C} \cdot \mathrm{D}$ 社へ求償 する

(7) 各社は弁護士や専門家費用の求償を互いにする.

h）調停当日

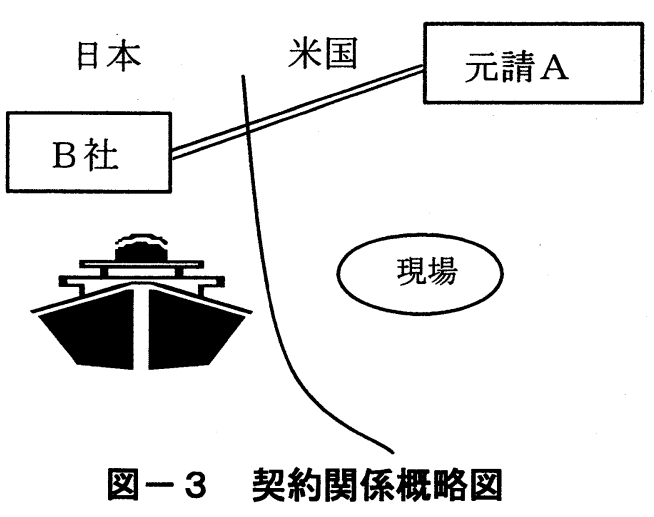

朝 9 時から調停人を介して全当事者が集結し調停が 開始された。まず，各々の主張を説明した後に，調停 人は，各社ごとに個別会議に入った. 調停人は, 個室 の各社を回りながら，係争を発展させた場合の費用対 効果を示唆しながら, 各当事者の主張の弱点を指摘し, 各社に譲歩を求めた. 最終的に大方均等な妥協を引出 し，同日の午後 8 時に調停は終了した．調停に要した 時間は 11 時間であり，スピーディな調停が可能であ ることを実感した。

\section{i ) 調停結果}

$\mathrm{D}$ 社は専門家を使い水素脆性の可能性は無いこと を証明し，且つ、A 社が通常行われている仮ボルトを 使用していない事、現場溶接前にボルト締めを行って いるという不備の証拠を示した。その結果、A社は後 掛かり費用の大半を放棄する結果となった。 B 社は, $\mathrm{C}$ 社（D社）への発注指示書の細微な不備や今後の係 争費用を考元，費用の応分の負担に合意した. C・D 社は多額の弁護士や専門家の費用を自己負担とする 一方，追加補償の支払は免れた。このような形で和解 が成立した。

\section{(2) 契約範囲に関わる係争}

\section{（事例その3：元請け↔下請け間の紛争）}

追加の製作工事を請け負ったが，契約範囲の解釈が 拮抗したため, 追加製作費を巡って係争となった事例 である。（図一3）

\section{a) 契約交涉}

日本の下請 $\mathrm{B}$ 社は，米国の元請 $\mathrm{A}$ 社から鋼析の製作 と輸送を請け負った. 入札時, B社が提出した見積条 件には「鋼析に添加する架設用資材として○○トンま でを価格に含む．それを上回る量については価格に含 んでいない」という一文を挿入した.

b ) 契約 
架設用資材の供給量については, その後も特に議論 されないまま契約に至った。最終的な契約書の表現は

「架設資材の供給もこの契約に含む」と単純化され， 見積条件書に示した数量や付帯条件は記載されなか った.

c ）追加範囲の要求

$\mathrm{B}$ 社による鋼析製作が開始されて数ヶ月後， $\mathrm{A}$ 社の 現場架設要領が固まった。 それに基づき， $\mathrm{A}$ 社は $\mathrm{B}$ 社 に架設資材の製作と取り付けを要請した. その必要数 量はB 社の見積時数量を遥かに上回るものであった.

\section{d) 解釈論争}

$\mathrm{B}$ 社は見積時の数量と決定数量の差分を追加費用 とし，A社に要求した，A社は契約の範囲内であると して譲らず，契約書の条項を盾にB 社の見積時数量を 承諾しなかった。 B 社はこれを不服として差分数量の 製作を中断することを $\mathrm{A}$ 社へ通告した.

e ）社外コンサルの起用

交涉は数ヶ月に及び平行線をたどった。そこでB社 は，米国建設業界に精通しているコンサルタントと弁 護士を起用し，契約諸条件の解釈並びに訴訟に到る場 合のケーススタディを行った。この結果，B社による 要求が妥当であることを検証し, 直ちに請負金の増額 を承認しない限り納入期日を保証しない旨通告した.

\section{f ）交渉決着}

$\mathrm{B}$ 社は，このクレームに起因する工期遅延に関わる 要求を放棄する代わりに, 見積時の数量を超過する差 分については請負金を増額するという決着に到った。

\section{（3）契約範囲関連のクレームに関する考察}

事例 2 からもわかるように，単なる規格ボルトの調 達仲介を請け負ったがために係争に巻き込まれる場 合がある. その結果, 自己防衛のための弁護士並びに その他人件費等の諸経費が発生した。

その費用が，当初予算の想定内に収まればよいが， 大きな係争に発展すると工事の損益に悪影響を与え かねない，仲介とはいえ，十分留意して契約条項を煮 詰めることの必要性を認識すべきである.

また, 調達のための発注指示書が原初契約と異なる 条件となる場合, 原初契約との整合性を満足させてお くことがリスクヘッジとなる.

事例 3 は，文書による確認を怠ったために係争にな った事例である.「見積時に提出してある」あるいは 「契約交涉時に口頭で議論し理解している」等のひと
りよがりは危険である．契約書の文章として反映され ない限り, 権利を主張するに当たり多大な労力を要す ることを肝に銘じるべきである。

この事例の場合, 見積条件書を契約の一部とするか, 契約書の中に明記すべきであったことは言うまでも ない.

米国では原初契約からの変更については発注者か ら書面で確認を得ておくことが基本である．さらに， 契約変更と思われる出来事が予見される場合には，規 定通りの期日内に契約変更を要請する通知を怠らな いことも基本である.この点, 発注者の口頭指示だけ で実質的な契約変更が生じる場合もある日本の契約 内容は，国際的には通用しないだろう。

カリフォルニア州の標準仕様書 ${ }^{1)}$ では,

(1) いかなる変更もエンジニアからの書面による指示 でなければ，請負者は発生した費用を請求する権 利を持たない。（Standard Specifications 4-1. 03D : 以下 SS とする. )

(2) 発注者に起因する変更が発生した日から 15 日以 内にその出来事に起因する時間的・費用的影響の 概算を書面で、請負者は発注者に通知しなければ ならない. 又, 斯かる工事作業を始める前に提出 しなければ， 発注者が追加費用や時間の延長を認 めない十分な理由となりえる。（SS 9-1.04）

（3）至急を要する場合は, 請負者は Force Account（掛 高, 時間で精算する取り決め) で発注者の指示に 基づき作業実施しなければならない。（SS9-1.03）

(4) 発注者は、虚偽の請求行為に対してはクレーム請 求額の 3 倍を原告側に支払わせる事が出来る（GC Sec. 12650-12655)

と明記されている.

以上のように，日本と異なり米国では当初契約から 変更が生じる場合は，請負者はそれに起因する金銭 的・時間的な影響を期限内に発注者一通知し, その後 の損害賠償請求権を留保しておかなければならない ことがわかる.

これに対し，日本では契約内容の詳細を明文化せず， 『別途協議』という表現を用いる場合がある，民族的 文化あるいは信義則が背景となり，『別途協議』によ る合理的な解決を可能にする場合が多いからである が，異文化圈で活動する場合には別の対応と認識が必 要である。 


\section{5.『契約精神』に関わる日本企業への提言}

ここまで筆者らが実際に体験した三つの紛争事例 を中心に, 米国の建設マネジメントの一端を述べてき た。これにより，米国のように契約に基づいた文化が 定着している社会では，権利と義務と責任が明確であ る一方，発注者と請負者の立場が対等であることや， 契約マネジメントの目的が “経過を透明化するプロセ ズ”であることが解明できた，さらに，経過を見せる 契約マネジメントは，納税者である国民に対する説明 責任を果たす機能を負っていることがわかった.

このような米国の契約マネジメントの実態を研究 し，できる範囲内で日本への導入をはかるがことが望 まれるのは言うまでもない，他方，特殊な風土に根ざ した特殊な建設業界が成熟していると言われる日本 の建設業が，米国内あるいは第三国において欧米と伍 していくために，何を改善すればよいか.

ここでは，民間企業の立場から努力できる具体策を 提言してみたい。

\section{（1） 米国の大学教育への参加}

米国の大学の教育理念は, いわゆるアメリカ実用主 義に立脚しており，とりわけ大学と社会との緊密な連 携を重視している ${ }^{14)}$. 工学教育も実用的な視点から研 究課題を選び，積極的に社会環境や地域社会に対する サービスに㗢きかけるものでなければならない，一例 として, カリフォルニア大学バークレー校の都市環境 工学科のカリキュラムを抜粋する ${ }^{15)}$.
A. プロジェクトマネジメント工学
B． 国際建設工事及びエンジニアリングにおけるマー ケティングとマネジメント
C. 建設工事における自動化
D. プロポーザルの準備とプレゼンテーション
E．工程計画並びに資源配分
F．リスクマネジメント
G．プロジェクト評価と資金調達
H. エンジニアのための法律学

いかにも実践的であることがわかる。このような実 践的教育を受けた学生が社会人となり，建設に関わる さまざまな分野で役割を果たしているのが米国であ る.

そうした社会に受け入れられ，ビジネスにおいて対
等な立場を主張するためには, 米国式の大学教育を熟 知することがもっとも有効な人材の促成栽培である.

日本の企業の場合，企業留学制度を取り入れている ところも多い. だが大半はきわめて細分化された専攻 分野の研究を目的としており，上記のような広汎なマ ネジメント研究のための制度は少ない.

専門的研究を目指した海外留学制度を否定するも のではないが，グローバルな展開を企図する企業であ るならば，即戦力として実務に適用できる教育に力を 注ぐべきではないだろうか.

\section{（2）アドミニストレーターの银成}

日本企業がOD A 等で海外工事を行なう場合，アド ミニストレーターという職位を設定する場合が多い.

一般に日本が資金提供するOD A 案件では，現場が 海外であることを除き，大半の要領と手順は国内工事 と類似している ${ }^{2)}$ 。このため, 特別な専門知識や高度 なマネジメント・スキルがアドミニストレーターに求 められる場合は少ない。いわば，アドミニストレータ 一は『総合管理官』として技術分野を除く広範な業務 分野を単独あるいは少数で委任されている.

一方，米国内での建設工事を初め，国際競争入札を 基本とする建設契約においては，アドミニストレータ 一の責務は重大である。 O D A 案件の場合のように， アドミニストレーターが総合管理する体制は危険だ といわざるをえない.

標準的な米国元請の工事推進組織の例を挙げると， アドミニストレーターの役割は以下の様に専門化し 高度に分類されている ${ }^{16)}{ }^{17)}$ 。

(1) Contract Manager (契約管理責任者)

(2) Office Engineer（工務技師）

《文書管理·事務所運営含む》

(3) Cost Engineer（原価管理技師)

(4) Accountant（会計・税務）

(5) Estimate Engineer (見積技師)

(6) Schedule Control Engineer (工程管理技師)

(7) Procurement Engineer（調達技師)

(8) Public Relation Manager (広報, Web 担当)

各分野は兼務ではなく，それぞれ専門担当者が対応 している。これに加えて弁護士やクレームコンサルタ ントを適宜活用している．米国元請が契約マネジメン 卜を如何に重要視しているかが理解できるだろう.

日本の企業が工夫すべきプロジェクト組織として， 
アドミニストレーター機能の分析と再配置を促した い.

\section{（3）社外コンサルタントの統治}

昨今, 日本の企業が国外で活動する場合, 外部の専 門家や外国人コンサルタントを雇用する事例が増え ている.

その一方, 雇用した専門家や外国人コンサルタント を十分に活用できず，内部摩擦が生じ，場合によって は短期間で解雇する事例もある。筆者らが知る外国人 コンサルタントたちの中には「日本の企業の対応はア ンフェアだ」と漏らす人も少なくない.

外国人コンサルタントや外部専門家を上手に活用 するためには，どんな点に留意すべきだろうか，それ をここで考えてみたい.

第一の要諦は，雇用の時期である. プロジェクトの 初期段階, できれば契約交涉の時点から起用すること が有効である. なぜなら, 契約後では優秀なコンサル タントや弁護士であっても状況を完全に覆すことは できないため，費用対効果を発揮しにくいからである。

第二は，外国人コンサルタントや外部専門家との接 触役を固定することである．できれば一対一対応が望 まれる. 外国語を理解できることと外国人の助言を活 用できることは似て非なものである．彼らの提言や見 解を的確に理解し，自ら問題点を掘り下げられる接触 役でなければ, 外国人コンサルタントや外部専門家と 意思疎通することは大変難しい。

高給で識見が高い彼らを上手に活用できれば，費用 に倍する効果を生むことができる．彼らを統制できる 仕組みづくりこそ，今後日本企業が研究すべき第三の 課題であると考える.

\section{6. おわりに}

筆者らの一人は, 約 30 年米国の橋梁建設工事に関 わってきた. その間, 元請者, $\mathrm{J} \mathrm{V}$ パートナー, エン ジニアリング・コンサルタント, 下請者として多くの 立場を経験した。初期には右往左往したが，多年の効 用のせいか近年は漸く米国の建設契約の要諦が理解 できるようになっていた。

一方, 他の二人の筆者は長く国際工事の経験は有す るものの, 米国の建設契約は初めて遭遇するものだっ た. 二人は, 本工事の後半から米国内に常駐し, クレ 一ムの提起と解決に専心した. その過程で, 多数の米
国人弁護士や米国人コンサルタントを起用し, 彼らと の共同作業を経験した。 また，クレームの諸段階で発 注者や元請との協議や折衝も経験した. 両方の体験を 通じ，短期間に米国の契約精神に習熟することができ た.

その結果，本稿の事例で示したように，契約の権利 と義務を遵守しつつ対手から損害賠償を求償する契 約マネジメントにも精通することになった. 今後, 日 本の建設業が国外に場を求める機会が増えるにつれ， このような体験を積む日本人技術者が増加し，それを 自企業の意識改革に活用していくならば，日本の建設 業のグローバル化は大いに促進される.この点で, 本 稿がこれから初めて国外工事に取組む技術者の参考 に供するならば幸いである。

米国の建設工事では, クレームによって求償できる 請負金変更は少なくない，時には，原初の契約金額に 相当するほどに上る. 企業の損益にとって甚大な影響 を与える．無論，筆者らが求償した金額も小額ではな い.これを逆に言うと，もし契約マネジメントについ て無知であれば，当然得られたはずの利益をみすみす 消失させてしまう結果になる.

契約マネジメントに関わるスキルを向上させなけ ればならない理由がここにある，そのためには，日本 人技術者が欧米の技術者に伍して交わり，正しい知識 や論理あるいは契約精神や議論戦略によって，対等な 立場で折衝や交渉に臨めるよう研鑚すべきである.

なお，本稿をまとめるに当たり，東京大学小澤一雅教授 から貴重な助言を多くいただいた。記して謝意を表する次第 である。

\section{【参考文献】}

1) State of California, Department of Transportation;Standard Specification 1999

2）中村裕司；建設技術者が危ない，日刊建設通信 新聞社, 2002

3) Office of Legislative Counse1;California Public Contract Code

4) Office of Legislative Counsel;California Civil Code

5) Office of Legislative Counsel;California

Streets \& Highways Code

6) Office of Legislative Counsel;California 
Government Code

7) America Arbitration Association : The Construction Industry' s Guide to Dispute Avoidance and Resolution

8) America Arbitration Association : Dispute Resolution Board Guide Specification

9) America Arbitration Association : Building Success for 21st Century

10) America Arbitration Association : Construction Industry Arbitration Rules and mediation Procedure

11) Ernest C Brown: The art of construction mediation, America Arbitration Association

12) Quenda Behler Story: Contractor's plain-english Legal Guide, Craftsman

13）草柳俊二 ; 21 世紀型建設産業の理論と実践, 山 海堂, 2001

14）土木学会コンサルタント委員会編 ; 国際的な構 造設計技術者の育成， 2000

15) http://www. berkeley. edu

16) Project Management Institute;PMBOK Guide 2000

17）土木学会建設マネジメント委員会 ; 第 18 回建 設マネジメント問題に関する研究発表・討論会 講演集，日・欧米型の PM の特徵に関する基礎的 調査, 2000

18）財団法人商事法務研究会； 英米商事法辞典

\title{
Eyes on Contract Management through Variety of Claims
}

\author{
By Yuji NAKAMURA, Masahiro YANAGIHARA and Yoshiki KOHAMA
}

Claims are popular in construction industry of the US. However, few Japanese exercises real claims. Claims are not mere "complaints" nor "demands" for money increase. They are results of accumulated logical contract rights and a stock of proven contractual facts.

This paper attempts to contribute to verify how the claim can be initiated, processed and terminated. Also, various practical methods to resolve claims during and/or after the Contract are discussed.

Finally, the paper proposes what in Japanese Contractors shall be improved for them to accord with and compete to the U.S. Contractors. 